\title{
The Politics of the Estranged Poor
}

\section{Citation}

Hochschild, Jennifer L. 1991. The politics of the estranged poor. Ethics 101, no. 3: 560-578.

\section{Published Version}

http://dx.doi.org/10.1086/293317

\section{Permanent link}

http://nrs.harvard.edu/urn-3:HUL.InstRepos:3198691

\section{Terms of Use}

This article was downloaded from Harvard University's DASH repository, and is made available under the terms and conditions applicable to Other Posted Material, as set forth at http:// nrs.harvard.edu/urn-3:HUL.InstRepos:dash.current.terms-of-use\#LAA

\section{Share Your Story}

The Harvard community has made this article openly available.

Please share how this access benefits you. Submit a story.

\section{Accessibility}




\section{CHICAGO JOURNALS}

The Politics of the Estranged Poor

Author(s): Jennifer L. Hochschild

Source: Ethics, Vol. 101, No. 3 (Apr., 1991), pp. 560-578

Published by: The University of Chicago Press

Stable URL: http://www.jstor.org/stable/2381469

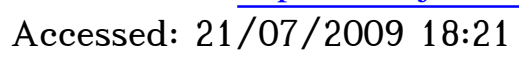

Your use of the JSTOR archive indicates your acceptance of JSTOR's Terms and Conditions of Use, available at http://www.jstor.org/page/info/about/policies/terms.jsp. JSTOR's Terms and Conditions of Use provides, in part, that unless you have obtained prior permission, you may not download an entire issue of a journal or multiple copies of articles, and you may use content in the JSTOR archive only for your personal, non-commercial use.

Please contact the publisher regarding any further use of this work. Publisher contact information may be obtained at http://www.jstor.org/action/showPublisher?publisherCode=ucpress.

Each copy of any part of a JSTOR transmission must contain the same copyright notice that appears on the screen or printed page of such transmission.

JSTOR is a not-for-profit organization founded in 1995 to build trusted digital archives for scholarship. We work with the scholarly community to preserve their work and the materials they rely upon, and to build a common research platform that promotes the discovery and use of these resources. For more information about JSTOR, please contact support@jstor.org. 


\section{The Politics of the Estranged Poor*}

\section{Jennifer L. Hochschild}

Question: What do ostriches and too many commentators on the urban underclass have in common? Answer: they hide their heads in the sand to avoid facing certain unpalatable facts. Ostriches differ from commentators, of course, in what they are hiding from. Ostriches fear lions. Commentators fear evidence that challenges their assumptions about how the world works or their prescriptions for how to improve it. For obvious reasons I will not further consider ostriches; instead, I will use William Julius Wilson's recent powerful book, The Truly Disadvantaged, to show how politically disparate commentators systematically attend to and ignore different features of the urban underclass. That analysis will provide the context for discussing the philosophy and politics of apportioning blame and assigning responsibility for improving the situation of the urban poor.

First a note on terminology. The Truly Disadvantaged gives the best possible justification for the term "underclass." In Wilson's view, its pejorative connotations are a useful corrective to liberals' ostrich act of the 1970s and early 1980s - their refusal to recognize publicly that the behaviors and presumably attitudes of many black inner city residents have sharply deteriorated in recent years. "It is ... true that certain groups are stigmatized by the label underclass, ... but it would be far worse to obscure the profound changes in the class structure and social behavior of ghetto neighborhoods by avoiding the use of the term underclass." 1

Obscuring unpalatable changes is a mistake. But so is needless stigmatization. The term "underclass" offends enough poor (and middleclass) blacks, and encourages enough well-off whites to distance themselves from the problems of inner cities, that its defects outweigh its virtues.

* My thanks to Elijah Anderson, Deborah Baumgold, John Deigh, John DiIulio, Monica Herk, Mark Kamlet, Dale Marshall, Dianne Pinderhughes, Clarence Stone, Eric Uslaner, Peter VanDoren, and participants in faculty seminars at Columbia University, Yale University, and the University of North Carolina at Greensboro.

1. William J. Wilson, The Truly Disadvantaged: The Inner City, the Underclass, and Public Policy (Chicago: University of Chicago Press, 1987), p. 8. Further references to this book will appear parenthetically in the text.

Ethics 101 (April 1991): 560-578

(C) 1991 by The University of Chicago. All rights reserved. 0014-1704/91/0103-0023 $\$ 01.00$ 
"Underclass" has other, more analytic, defects. It evokes the image of a class structure in a society that denies that the nonpoor are arrayed in classes. It elides the crucial question of the connection between longterm poverty and "deviant" behavior and attitudes. It assumes a sharp distinction between its members and the merely poor or merely badly behaved (by mainstream standards).

Instead of "underclass," therefore, I propose the term "estranged poor." My term has the defect of an additional word, but also several virtues. It sets boundaries by making explicit the fact that the population in question is both poor and "deviant." It avoids the anomaly of invoking class on the bottom rung of American society while ignoring the existence of classes further up the ladder. It does not imply a sharp break between some people and others who are only poor or only estranged. Finally, "estranged poor" lacks the pejorative connotations of "underclass."

I have spent so much time on the boring issue of terminology because this topic is such a political minefield that one must take exceeding care with one's language. Wilson, for example, has been unnecessarily misunderstood because of his lack of attention to (in The Declining Significance of Race) or misjudgment about (in The Truly Disadvantaged) the political connotations of certain words. I seek to avoid the same misunderstandings by avoiding the most contentious term, the "underclass."

\section{WHAT WE KNOW ABOUT THE ESTRANGED POOR}

The literature on the estranged poor yields three conclusions: The number and difficulties of the estranged poor grew during the 1970s and 1980s because of foreseeable, intelligible, and avoidable choices made by other Americans. Some of the estranged poor are profoundly alienated from, and alien to, the rest of American society. The estranged poor engage

is.

3. One of the deepest difficulties in studying the estranged poor is the question of race. In popular usage "underclass" usually implies black (and occasionally Latino). Several studies do show the estranged poor to be disproportionately black and Latino. See Robert Reischauer, "The Size and Characteristics of the Underclass" (paper presented at the annual meeting of the Association for Public Policy and Management, Bethesda, Md., October 1987); and Erol Ricketts and Ronald Mincy, "Growth of the Underclass: 1970-1980" (Urban Institute, Washington, D.C., 1988). However, among people living in "underclass" neighborhoods, the proportion of blacks declined from 77 percent in 1970 to 59 percent in 1980, while the proportion of non-Hispanic whites increased from 14 percent to 28 percent, and the proportion of Hispanics increased from 8 percent to 10 percent (Ricketts and Mincy, table 6). Nevertheless, because most behavioral and economic data are presented by race, because Wilson focuses on the black underclass in The Truly Disadvantaged, and because political battles about the "underclass" are usually disguised battles about race, I will focus on the African American segment of the estranged poor. 
in exaggerated and distorted versions of activities that many other Americans also engage in. Let us consider each conclusion in turn.

\section{Other Americans' Political Choices}

First, many analysts have shown how Americans' social, economic, and political choices have produced an inner city population that is disproportionately poor, uneducated, nonworking, born to unmarried mothers, and involved in crime. The Truly Disadvantaged cites the effects of a history of racial discrimination, immigration policy at the turn of the century, the changing age structures of ethnic and racial groups, the recent shift from manufacturing to service industries, firms' migration to southern suburbs and Third World countries, the slack economy of the 1970s and early 1980s, white women's movement into the labor force, and successful blacks' movement out of ghettos-all to explain the increasing poverty and joblessness of urban blacks. One can add other culprits, such as persistent if more subtle racism, demoralized and deteriorating urban schools, federal support for freeways and for racially segregated suburbs in the 1940s and 1950s, gentrification and a deteriorating stock of lowrent housing, the declining real value of Aid to Families with Dependent Children (AFDC) and the minimum wage during the 1970s and 1980s, the rising tax burden on the poor during the same period, and the drive to reduce inflation at the expense of rising unemployment in the late 1970 s.

This laundry list must be sorted to be of much analytic use. But its very length and breadth suggest how powerfully structural and institutional choices explain the growth of the estranged poor. One set of studies, in fact, leaves the reader astonished that any black or poor resident of a Northern city has escaped total devastation.

The list is most usefully sorted according to the feasibility of intervention to offset or reverse its harmful impacts. Some items-immigration policy around the turn of the century and demographic differences among ethnic groups - were never or are not now easily remedied. They result from political choice only in a very attenuated way. But most phenomena normally thought of as economic or social-and thus out of the hands of political actors-are amenable to policy intervention. Wilson has been appropriately criticized for treating the switch from a manufacturing to a service economy and the suburbanization of industries and the middle class as inevitable results of impersonal economic forces. ${ }^{4}$ After all, if enough politically active Americans wished it, state legislatures and Congress could do more to prevent or retard plant closings, to make capital flight overseas more costly, to encourage the manufacture of basic goods, to foster entrepreneurship in depressed communities, and to enhance the quality of life in central cities. These policies would not fully succeed, and their benefits might not turn out to outweigh their costs. But they

4. Adolph Reed, Jr., "The Liberal Technocrat," Nation (February 6, 1988), pp. 16770. 
could be tried; the political system is not a helpless pawn in the hands of impersonal capitalism or omnipotent capitalists. But Americans, at least as their legislators interpret them, have not wished to make strenuous efforts to control the economic system, and so we have not done so. The consequences for big cities of losing many entry-level jobs were surely predictable, at least in broad outline; in that sense the growth of the estranged poor because of changes in the economic structure was a political choice.

Other items on the laundry list are even more obviously political choices, and thus even more amenable to policy intervention. It does not take a genius to see that reducing the value of AFDC payments and the minimum wage while increasing the tax burden on the poor is going to worsen the situation of the worst-off. Similarly, plenty of evidence shows that unemployment hurts poor people worse than inflation does, so fighting the latter by permitting the former to rise has predictable effects on the poor. ${ }^{5}$

I cannot here discuss in detail the structural causes of deepening estrangement and poverty among urban African Americans. My point is simply that no one who reads the literature on "the underclass" can miss the compelling evidence for the point Wilson insists on: the situation of the estranged poor results largely from "a complex web of . . f factors [that shape] the structure of constraints and opportunities" (pp. 61-62).

\section{Destructive Norms and Behaviors}

The second point addresses culture and behavior rather than political choices and economic structures. Some of the estranged poor hold "deviant" values, and act in ways that are frighteningly destructive of themselves, their children, their neighbors, and the social fabric of the nation.

Journalists are often best at capturing this facet of the estranged poor. For example, Pete Hamill, citing his long-term liberal credentials and "bone-poor" ethnic origins, wrote in 1988 about the "underclass ... living in anarchic and murderous isolation.... In the last decade, I've watched this group of American citizens harden and condense, moving even further away from the basic requirements of a human life: work, family, safety, the law... . This ferocious subculture [is] the single most dangerous fact of ordinary life in the United States."6

Journalists are most useful in their concrete accounts of how particular people and events manifest "ferocity." The Liberty City, Miami, rioters of 1980 "were different. [In the past] white people got hurt because they got in the way or because they provoked a confrontation. In this riot, the purpose was to kill white people. That's a whole new ballgame to

5. Rebecca Blank and Alan Blinder, "Macroeconomics, Income Distribution, and Poverty," in Fighting Poverty, ed. Sheldon Danziger and Daniel Weinberg (Cambridge, Mass.: Harvard University Press, 1986), pp. 180-208.

6. Pete Hamill, "Breaking the Silence," Esquire 109 (1988): 91-102. 
deal with." 7 Black youths fought over an ax with which to beat a white passerby; one white victim had his ears and tongue cut off; rioters prevented an ambulance from reaching three dying white teenagers. Indeed, the nation had not seen such concentrated racial savagery since the almost daily lynchings of the Jim Crow decades.

Some drug dealers and users similarly reject normal conventions of concern for themselves and others. After watching the execution of a former friend who had brought trouble to their gang, a seventeen-yearold crack dealer explained, "It's all part of the game. A snitch or someone who puts friends in danger don't need to be living." ${ }^{8}$ Teenage girls are prostituted to obtain crack for their mothers; women hide their belongings and sometimes their grandchildren from their own daughters to prevent theft and destruction. ${ }^{9}$ A child begs his teacher, "Please don't make me go home. I don't want to go back there," because "my mother don't take care of me. All she want is drugs." 10

These impressionistic, even sensationalist, images are reinforced by more sober academic analyses. One ethnographer of poor urban blacks argues that

the relationship between "the old head" ["a man of stable means who believed in hard work, was committed to family life, church life, and ... to passing on ... (his) philosophy of life"] and the "young boy," an important institution of the ghetto, is presently undergoing profound stress and some change. The situation reflects the general sense of alienation, lack of opportunity, and demoralization of certain aspects of the black community. ... When work and other rewards are not forthcoming, young boys easily reach the conclusion that the old head's moral lessons concerning the work ethic, punctuality, and honesty are not applicable to the presentday situation. ... The influx and expansion of the drug culture has created a new role model who is young, often a product of a streetgang, makes money fast, and scorns the law and traditional values. ${ }^{11}$

Another claims that black youths deliberately fail in school because "learning to follow the standard academic practices of the school are often equated by the minorities with ... 'acting white' while simultaneously giving up acting like a minority person. School learning is therefore ... perceived

7. George Lardner, Jr., and Margot Hornblower, "Miami: Brutality Was Not Expected," Washington Post (May 25, 1980), pp. Al, A16.

8. Michael Dorgan, "Lives Going up in Smoke," San Jose Mercury News (February 28, 1988), pp. 1, 18a.

9. Gina Kolata, "In Cities, Poor Families Are Dying of Crack," New York Times (August 11, 1989), pp. A1, A13; Jane Gross, "Grandmothers Bear a Burden Sired by Drugs," New York Times (April 9, 1989), pp. 1, 26.

10. Michele Norris, "6-Year-Old's Md. Home Was a Modern-Day Opium Den," Washington Post ( July 30, 1989), pp. 1, 22, 23.

11. Elijah Anderson, "Of Old Heads and Young Boys" (University of Pennsylvania, Sociology Department, Philadelphia, 1986), pp. 10, 13, 19. 
as a subtractive process: a minority person who learns successfully in school or who follows the standard practices of the school is perceived as becoming acculturated into the white American cultural frame of reference at the expense of the minorities' cultural frame of reference and collective welfare." 12 A few scholars even dare to say that "the most persuasive interpretation of nonworking psychology, especially for welfare mothers, is what in the 1960s was referred to as culture of poverty. ... For them, work is something they would like to do, but not something they feel they must do at any cost. It is an aspiration but not an obligation." 13

Statistical analyses concur with at least the most general version of these claims. Teenage black women who expect to become mothers before marrying, whose friends or sisters are sexually active, and who violate conventional norms of adolescent conduct (e.g., cutting classes, skipping school, committing infractions that lead to school suspension or probation) are much more likely to have a child within two years of graduating from high school than more conventional but otherwise similar women. ${ }^{14}$ Young black men living in poor inner cities in 1979 "who believed having a good education was very important, who believed that the unemployed could find work if they wanted, and who did not report that most of their friends were unemployed averaged almost 150 more hours of work per year than the remaining respondents. Similarly, those who stated that religion did not play a strong role in their lives worked significantly fewer hours." "Some of these studies leave ambiguous whether "deviant" values cause "deviant" behavior or vice versa, but they at least make it clear that more than a few poor people hold values and take actions far outside the mainstream, and that these values and actions inhibit their already dim chances for mobility out of the impoverished ghetto. ${ }^{16}$

12. Signithia Fordham and John Ogbu, "Black Students' School Success," Urban Review 18 (1986): $1-31$.

13. Lawrence Mead, "The Logic of Workfare," Annals of the American Academy of Political and Social Science 501 (1989): 162.

14. Dennis Hogan, "Structural and Normative Factors in Single Parenthood among Black Adolescents" (paper delivered at the annual meeting of the American Sociological Association, San Antonio, Texas, 1984), pp. 16, 19, tables 3, 4, 5; Allan Abrahamse, Peter Morrison, and Linda Waite, Beyond Stereotypes: Who Becomes a Single Teenage Mother? (Santa Monica, Calif.: RAND Corp., 1988); and Frank Frustenberg, S. Philip Morgan, Kristin Moore, and James Peterson, "Race Differences in the Timing of Adolescent Intercourse," American Sociological Review 52 (1987): 511-18.

15. Linda Datcher-Loury and Glenn Loury, "The Effects of Attitudes and Aspirations on the Labor Supply of Young Men," in The Black Youth Employment Crisis, ed. Richard Freeman and Harry Holzer (Chicago: University of Chicago Press, 1986), pp. 386-87.

16. This observation raises the question of our goal for the estranged poor. Should the political agenda be to enable them to move into the ranks of the "merely" struggling poor? Their children would probably be better off in such circumstances, but they themselves might not be, or at least might not think that they were. This is not the place to discuss what should lie beyond movement from estranged poverty into mainstream poverty, but if the latter is all our political system can or is willing to offer, American society is impoverished in more ways than one. 


\section{Exaggerated Reflection of Other Americans' Norms and Behaviors}

The final conclusion I draw from the literature seems to contradict the one just drawn. In some ways the estranged poor act very much like other Americans, except that they do more of whatever the rest of us do and are harmed more in the doing.

Consider one widely accepted behavioral definition: "underclass neighborhoods" are populated by a disproportionate number of high school dropouts, adult men working less than half time, welfare recipients, and female-headed households. ${ }^{17}$ In the decade after 1970, underclass neighborhoods in eight large "distressed" metropolitan areas experienced increases in the mean levels and decreases in the coefficients of variation for three of these four measures (the exception is high school dropouts). In other words, the " 'worst' neighborhoods of these metropolitan areas have gotten worse, but so have the 'average' neighborhoods; and, if anything, the 'average' neighborhoods have worsened to a greater extent." The claim of a growing underclass incorrectly "associates a local, identifiable subpopulation with problems more accurately associated with the general population. If female headship and irregular employment are 'underclass' characteristics, then we are an 'underclass' society, not a society with an 'underclass.'" 18

A similar story emerges for other measures of disadvantage or deviance considered over time. The unemployment rate for young white civilian men rose from 10 percent in 1950 to about 18 percent in 1983. For similarly situated blacks, the unemployment rate rose from 12 percent to about 40 percent. ${ }^{19}$ The proportion of white men in the civilian labor force dropped from 86 percent in 1954 to 77 percent in 1987; the analogous proportion of black men dropped from 85 percent to 71 percent. ${ }^{20}$ Thus men of both races have been working less since the 1950s, but the change came sooner and was much greater among blacks.

The proportion of children born to unmarried mothers shows the same trend: an increase in both races, with a higher starting point and earlier and faster growth among blacks. "Between 1940 and 1960 the proportion [of children born] out of wedlock rose from 17 to 22 percent among blacks and rose to 59 percent in 1984. Among whites, there was

17. Erol Ricketts and Isabel Sawhill, "Defining and Measuring the Underclass," Journal of Policy Analysis and Management 7 (1988): 316-25.

18. Mark Hughes, "Concentrated Deviance and the 'Underclass' Hypothesis" (Princeton University, Woodrow Wilson School, Princeton, N.J., July 1988), pp. 10-11. Ricketts and Mincy, tables 4 and 5, use different methods but find the same results.

19. Data before 1971 refer to whites and nonwhites (of whom about 85 percent are black) (Reynolds Farley and Walter Allen, The Color Line and the Quality of Life in America [New York: Russell Sage Foundation, 1987], p. 214).

20. Data before 1970 are for nonwhite men (U.S. Bureau of the Census, Historical Statistics of the United States, Colonial Times to 1970 [Washington, D.C.: Government Printing Office, 1975], vol. 1, table D 42-48, and Statistical Abstract of the United States, 1989 [Washington, D.C.: Government Printing Office, 1989], table 621). 
almost no change during the 1940s or 1950s, but between 1960 and 1984 the proportion of births occurring to unmarried women increased from 2 to 13 percent." 21

Just as blacks are in this peculiar sense "leading" whites, so poor blacks are "leading" well-off blacks. For example, poor black men are less likely to marry than they used to be-but so, to a slightly lesser degree, are well-off black men. ${ }^{22}$

Consider finally the use and sales of illegal drugs. Washington, D.C., for example, has earned the epithet "Dodge City" because of its skyrocketing, largely drug-related, homicide rate since $1988 .{ }^{23}$ The publicity has been constant, nationwide, and sensational.

What is less publicized is the possibility that Washington suburbanites (roughly, affluent whites) ingest more cocaine per capita than do District residents (roughly, poor blacks). In 1986, 1.89 out of a thousand emergency room visits in the District and 2.83 such visits in the suburbs cited cocaine use. ${ }^{24} \mathrm{~A}$ smaller proportion of high-school students in the District than in Prince George's or Montgomery Counties have used cocaine. Students

21. The increase in the proportion of births to unmarried women has slowed or even halted among blacks since 1970 but continues among whites (Farley and Allen, pp. 77, 79). Readers inclined to argue that there is nothing wrong (even if "deviant") in having a child outside of marriage-a position I share, in the abstract-should consider the consequences of unmarried motherhood for the children. In 1975, 14 percent of all black children, but 26 percent of black children in female-headed households, lived in homes with incomes below half the poverty level. By 1987, fully 23 percent of all black children and 38 percent of black children in female-headed households lived in such deep poverty. The trends are similar but less severe for whites. Four percent of all white children and 15 percent of white children in female-headed households lived below half of the poverty line in 1975; in 1987, 6 percent and 23 percent, respectively, did so (calculations from U.S. Bureau of the Census, Current Population Reports, Characteristics of the Population below the Poverty Level: 1975, P-60, no. 106 [Washington, D.C.: Government Printing Office, 1977], table 7, and Poverty in the United States: 1987, P-60, no. 163 [Washington, D.C.: Government Printing Office, 1989], table 4).

22. Christopher Jencks, "Deadly Neighborhoods," New Republic 201 (June 13, 1988): 28.

23. Estimates of the proportion of 1988 killings in the District that had motives related to drugs range from 58 percent to 80 percent, as compared with 16 to 21 percent in the pre-crack days of 1985 (Richard Morin, "Demographic Line between Slain, Slayer Indistinguishable," Washington Post [January 1, 1989], pp. A1, A23; Office of Criminal Justice Plans and Analysis, Homicide in the District of Columbia [Washington, D.C.: Office of Criminal Justice Plans and Analysis, 1988], p. 23).

24. These data are unreliable. Not all hospitals report them; more poor blacks live in the suburbs of Washington, D.C., than in the suburbs of most cities; "wealthier users are more likely than poorer users to go to a private physician rather than to an emergency room, in case of an adverse drug experience." The first caveat suggests that the overall figures are too low. The second suggests that these data exaggerate the distinction between poor black city and well-off white suburbs. The third suggests that these data underestimate that distinction. The quotation, data, and caveats are all from Peter Reuter, John Haaga, Patrick Murphy, and Amy Praskac, Drug Use and Drug Programs in the Washington Metropolitan Area (Santa Monica, Calif.: RAND Corp., 1988), p. 11. Washington, D.C., is unusual, though not unique, in the extent of drug use in the suburbs (ibid.). 
in Washington, but not in the two suburban counties, report proportionally less cocaine use than a national sample. ${ }^{25}$ More generally, in a national sample of young men, a larger percentage of whites than blacks reported using illicit drugs, even among out-of-school and nonemployed youths. ${ }^{26}$ Only among respondents older than thirty-five years does a higher proportion of blacks than whites use cocaine. ${ }^{27}$

Finally, many drug sellers bear an uncanny resemblance to American captains of industry. They work their way up the ladder: "I had to convince people I could do it. I didn't have my hand out for no charity. I worked hard to get established." They are self-disciplined and work-oriented: "Selling coke is just like any other business. You gotta work hard, stay on your toes, protect what's yours." They are patriotic: a graffito in a Latino neighborhood of New York reads, "God bless America and the Yankee dollar." They defer gratification: "I never use cocaine; it's not real when they say that a person that sells ends up using his drugs; that's not true, he's like an outcast." ${ }^{28}$ They develop detailed job descriptions for subordinates, write manuals to rationalize the flow of goods, learn salesmen's manners, use brandnames to distinguish their product from their competitors', and provide discount coupons, two-for-one sales, and contests for employees. ${ }^{29}$

In the end, it is sellers' resemblance to junior members of the Chamber of Commerce that makes them and their trade so frightening to other Americans. Were they less like us, we could dismiss them as merely crazy or evil. But the combination of a product as tempting as it is horrifying, and behavior as rational as it is destructive, ${ }^{30}$ is extraordinarily hard to cope with, psychologically and politically.

In short, the estranged poor are engaging in exaggerated-thus highly visible and frightening - versions of the same "deviant" behaviors as many of the rest of us. Fewer Americans of all races and classes are holding jobs, getting or staying married when they have children, abstaining from illegal drugs. As Pogo said, "We have met the enemy, and he is us." 31

25. Ibid., p. 23.

26. Richard Freeman, "Who Escapes? The Relation of Churchgoing and Other Background Factors to the Socioeconomic Performance of Black Male Youths from Inner-City Poverty Tracts," in Freeman and Holzer, eds., p. 360.

27. Reuter et al., p. 26.

28. The first three quotations are from Terry Williams, The Cocaine Kids: The Inside Story of a Teenage Drug Ring (Reading, Mass.: Addison-Wesley, 1988), pp. 32, 44, 24; the last is from Jerome Skolnick, "The Police and the War on Drugs" (lecture delivered at New York University Law School, April 18, 1989), p. 18.

29. Isabel Wilkerson, "Detroit Drug Empire Showed All the Traits of Big Business," New York Times (December 12, 1988), pp. 1, 42; Sari Horwitz, "A Drug-Selling Machine That Was All Business," Washington Post (April 24, 1988), pp. A1, Al6.

30. W. Kip Viscusi, "Market Incentives for Criminal Behavior," in Freeman and Holzer, eds.; Richard Freeman, "Help Wanted" (paper presented at the Conference on The Truly Disadvantaged, Northwestern University, Evanston, Ill., October 19, 1990).

31. A full treatment of the estranged poor would also deal with ways in which they are diverging from other Americans. On the one hand, the black homicide rate declined 


\section{Combining the Three Conclusions}

How do the three findings from the literature on the estranged poor fit together? In combination, they describe a group of people who have been prevented from following normal channels to social status, economic well-being, and political power but who have been taught to have the same desires for these good things as other Americans. The estranged poor react to this frustration in two ways. Some throw off the restraints that most people impose on themselves against violence, addiction, hatred, and irresponsibility and permit their worst impulses to swamp their best. ${ }^{32}$ Others (or the same people at different times) do more of what other Americans do to attain leisure time, wealth, happiness, and someone to love them. ${ }^{33}$ Thus the second and third claims-of "deviance" and "leadership" - are not in contradiction. They are both responses to structural constraints in the context of an apparent promise of equal opportunity, ${ }^{34}$ and they may comfortably coexist in the same community, even in the same person.

This complex stew of structural impediments, typical desires, and destructive actions is captured in the account of Isaac Fulwood, Chief of Police for Washington, D.C., and himself a product of a poor black District family. He reports: "1988 changed us. We can never go back to being what we were.... It's not just the volume of murders, it is the viciousness - the kinds of wounds that you see, ... where young people have had their kneecaps shot off, had their testicles shot off. . . . Today's kids are cocky. We ... charge them with taking another person's life, and there's no remorse. For them, it's just a matter of fact.... This is not the city that I grew up in. ... Something has changed to produce the kids that I see." Chief Fulwood describes a recently arrested eighteen year old with "a hard-working mother who is doing her best to provide

from 1970 to 1983, while the white homicide rate rose (Farley and Allen, pp. 42-43). On the other hand, in the 1970s the unemployment rate rose for young black men and fell for young white men and women (David Ellwood and David Wise, "Youth Employment in the Seventies," in American Families in the Economy, ed. Richard Nelson and Felicity Skidmore [Washington, D.C.: National Academy of Sciences Press, 1983], fig. 1). These complexities shade, but do not obviate, my point about the estranged poor precedingeven leading - other Americans down the wrong road.

32. Liberty City rioters' explanation of their behavior captures this connection between structurally induced frustration and rejection of conventional norms: "The white man ain't been doing us no good. So we didn't do him no good. The white man got the jobs and we don't got no jobs. The white man got everything and we got nothing. It ain't right" (Lardner and Hornblower, p. Al).

33. This analysis resembles the now traditional sociological notion of "value stretch" (see Hyman Rodman, "Lower Class Value Stretch," Social Forces 42 [1963]: 205-15; Herbert Gans, "Culture and Class in the Study of Poverty," in On Understanding Poverty, ed. Daniel P. Moynihan [New York: Basic, 1968], pp. 201-28; Elliot Liebow, Tally's Corner [Boston: Little, Brown, 1968]).

34. For a development of this theme, see Jennifer Hochschild, "Equal Opportunity and the Estranged Poor," Annals of the American Academy of Political and Social Science 501 (1989): 143-55. 
him with what he needs in life-not a wealthy family, but a working family. Yet this kid has 30, 40, 50 pairs of tennis shoes, all kinds of jogging suits, and he is defining himself in terms of these material things.... His world is not next year, not next week. His world is today. Instant gratification, right now." Asked how this arrested man thinks, Chief Fulwood speculates:

This kid doesn't see the same world that I saw when I was growing up, a world that was expanding, where there was hope, where I had the possibility to achieve. He's got to have it all, right now.... Because that's what he is, those material things, ... and he doesn't care about the impact of his behavior on other people. [Students say to me] "Chief Fulwood, you're full of bullshit. Why should I go and make $\$ 3.50, \$ 4.25$ an hour at a regular job? I can make that in one minute on the street. ... I can make all the money I want to make."

He concludes, in rather an understatement, "There's something insidious about what is happening." 35

It is all here - the lack of opportunity, the desire for yuppie jogging shoes and yuppie status, the downward spiral into utter solipsism, inability to empathize, and murder. We do not know enough to say precisely how these themes combine in which people, with what other characteristics. Nor is the whole sorry combination of constraints, desires, and murder limited to the estranged poor. ${ }^{36}$ But we do know that something is happening in the inner cities, enough to bring a police chief who has seen it all to despair.

\section{THE POLITICS OF ANALYZING THE ESTRANGED POOR}

This account of the three themes in the literature on the estranged poor-structural constraints, destructive values and acts, and exaggerated mirroring-provides leverage for understanding the politics of analyzing the estranged poor and the politics of initiating solutions to the problem. Let us consider each issue in turn.

On the politics of analysis: left-wing analysts too often emphasize the first but act like ostriches with regard to the second and third themes. Right-wing analysts too often emphasize the second but are equivalently blind to the first and third. Wilson in The Truly Disadvantaged has the compeling virtue of uniting the first and second theme-for which achievement he has received about equal opprobrium from both sides of the political spectrum-but he too underestimates the third.

35. Isaac Fulwood, Jr., "Washington's Year of Shame," Washington Post (January 1, 1989), pp. B1, B4.

36. As I write, the most vivid demonstration of the pathology of the estranged rich is Charles Stuart's murder of his seven-months pregnant wife, apparently for insurance money (see, e.g., Larry Martz, Mark Starr, and Todd Barrett, "The Boston Murder," Newsweek 115 [January 22, 1990]: 16-21). 
In lieu of exhaustively demonstrating this claim, I shall provide illustrative examples from the debate over The Truly Disadvantaged. First, Wilson's own position: The Truly Disadvantaged describes the "ghetto subculture" of violent crime, family dissolution, and welfare dependency in inner city neighborhoods. It argues that "a person's patterns and norms of behavior tend to be shaped by those with which he or she has had the most frequent or sustained contact and interaction" (p. 61) and muses that "it would be dogmatic to rule out . . . the possibility that some cultural traits may in fact take on a life of their own for a period of time and thereby become a constraining or liberating factor in the life of certain individuals and groups in the inner city" (p. 138). Nevertheless, Wilson insists that he is describing not a culture of poverty but rather the consequences of "social isolation," a concept that "highlights the fact that culture is a response to social structural constraints and opportunities" (p. 61). "Accordingly, the key conclusion from a public policy perspective is that programs created to alleviate poverty, joblessness, and related forms of social dislocation should place primary focus on changing the social and economic situations, not the cultural traits, of the ghetto underclass" (pp. 137-38).

Wilson is not alone in connecting cultural deviance with structural constraints. ${ }^{37}$ But he is the most famous, he is among the few blacks writing scholarly works on the subject, and he is arguably the most eminent. So he is the lightening rod for attacks from all directions.

Thus critics from the Left fault The Truly Disadvantaged for paying too much attention to the culture of poverty and too little attention to the structural causes of poverty. One sees The Truly Disadvantaged as "a very conservative analysis with very ominous implications.... As the term ['social pathology'] is applied in The Truly Disadvantaged, there is little question that the 'pathological' reference is to the behavior of that 'large subpopulation of low-income families and individuals whose behavior contrasts sharply with [that] of the general population,' rather than an economic system that requires a reserve army of unemployed persons, and who are thereby impoverished." Wilson's use of the term "underclass" is "ominous" because it "places the problem to be 'in the people,' . . not in ... an economic system in which they have been declared to be superfluous."38

37. For example, most analysts cited in the discussion of the second theme connect culture and structure. Not to do so- to argue that the culture of poverty is sui generisis to be more explicitly racist and elitist than any author is willing to be these days. "Culture of poverty" and "structural flaw" proponents, then, differ mostly in their emphasis on culture, their assumptions about culture's independence and staying power, and their policy prescriptions' focus on changing people or structures.

38. Robert Newby, "Problems of Pragmatism in Public Policy: Critique of William Wilson's The Truly Disadvantaged," Journal of Sociology and Social Welfare 16 (1989): 12332. 
Another reviewer similarly complains of Wilson's focus on the behavior of poor people instead of capitalists. "The Truly Disadvantaged fails ... to break with the premises of the Reagan era discourse on the poor.... Wilson's entire interpretation springs from the conjunction of two disturbing and retrograde emphases. ... These are, first, the focus on 'disorganization,' 'aberration,' 'deviance,' and 'pathology' . . and, second, a deeply patriarchal vision of 'mainstream' life." Wilson asserts "a need to 'restore' two-parent families without regard to the fact that such a project ignores the structural sources of poverty he describes. Moreover, he seems oblivious to the danger that the new concern with the black family ... is an empty, moralistic ideology that seeks to stigmatize the poor and enforce patriarchal institutions." 39

Critics from the Right fault The Truly Disadvantaged for paying too much attention to structural causes of poverty and too little attention to the flaws of the poor. Thus Wilson lacks "the courage to demand that black culture be radically altered to allow its entrance into mainstream American culture. ... What doesn't seem to have occurred to Wilson is that other groups have faced social isolation, severe unemployment, and depleted marriage markets, but have nevertheless adapted and succeeded. It is culture ... that determines how different groups will respond to the same hardship.... Wilson's prescription illustrates the depths of decadence to which politically correct thinkers have sunk."40

Another self-defined conservative critic praises Wilson for being "brutally realistic in describing the ghetto" and for "describ[ing] bluntly how crime and illegitimacy have escalated in the inner city." He nevertheless remonstrates that "even someone so hardheaded as Wilson finally acquiesces in the orthodoxy among liberal analysts, which is to assign all the responsibility for social problems to society itself, none to the poor. From such reasonings, government derives a mandate only to manipulate surrounding conditions, but not to govern the poor themselves so as to enforce civility." 41

My point here is not that The Truly Disadvantaged has been severely criticized-most commentators have (appropriately, in my view) praised it fulsomely. The point is also not that reviewers misread books, or even that they (deliberately?) misread books in order to ride their own hobbyhorses in reviews - that is news to no author. The point, rather, is that the issue of the estranged poor is so complicated and politically sensitive that analysts have an apparently almost irresistible tendency to focus on that part of the problem that fits their own preconceptions and to deny or ignore those parts that violate their preconceptions. Wilson is unusual, although not unique, in his effort to keep two apparently competing

39. Reed.

40. David Klinghoffer, "Twice as Truly Decadent," National Review 40 (March 4, 1988): 46-48.

41. Lawrence Mead, "The New Welfare Debate," Commentary 85 (1988): 48. 
unpalatable truths before the reader simultaneously. That he does not altogether succeed in that agenda is only slightly his fault.

But if I read the evidence on the estranged poor correctly, even Wilson has only a partial view. He, like most other analysts, does not see a third truth that is just as important and even more unpalatable. Other Americans are made so uneasy by the estranged poor because they are not only inhabitants of an alien culture or innocent victims of the capitalist juggernaut. They are, in an exaggerated and distorted way, us. ${ }^{42}$

\section{THE POLITICS OF HELPING THE ESTRANGED POOR}

This excursion into academic politics is important mainly insofar as it illuminates real politics; that is, perceptions of The Truly Disadvantaged matter because they help us to think about how the truly disadvantaged are to be enabled to escape their situation. The three interwoven themes described in the first section suggest that the reviewers of The Truly Disadvantaged (and the political analysts who I am using them to represent) are starting in exactly the wrong way.

More precisely, too many commentators and activists assume that the way to begin solving the problem of the estranged poor is to determine the most fundamental or important cause of their plight, and to identify who is to blame for that cause. Thus if capitalism creates ghetto poverty, the villains are capitalists and their minions, and the political prescription is struggle against them through government action and community activism. Or if misguided policymakers have made ghetto residents lazy or incapable, the villains are policymakers and perhaps the poor themselves, and the political prescription is more unfettered capitalism and individual initiative. The details of each prescription, of course, are endlessly debatable, but the general direction seems clear once one finds the basic cause and the worst villain.

Blaming has emotional as well as instrumental attractions. The Left wants to shift attention away from the antisocial actions of the estranged poor; the Right wants to divert gazes from the capitalist economy and self-interest-driven polity. Both sides are dismayed by the thought that the estranged poor mirror the rest of society. Leftists do not want to admit that the freedom to use drugs, dissolve or not enter into marriages, reject unattractive jobs can be so destructive. Right-wingers are just as reluctant to admit that the profit motive of the drug seller or the rationality of the welfare mother is the same as the profit motive of the investment banker or the rationality of the salary negotiator. In short, the ostrich act-finding one crucial cause, apportioning blame simplistically, and hiding from evidence that I and my affiliations are also culpable-has

42. I have seen only two reviews of The Truly Disadvantaged that make this point. They are Jencks; and Charles Willie, "Rebuttal to a Conservative Strategy for Reducing Poverty," Policy Studies Review 7 (1988): 865-75. The latter review is mean-spirited and factually mistaken in places, however, so I do not associate myself with most of its arguments. 
many appeals. Apportioning blame in complex ways that hit close to home has correspondingly few.

But if my reading of the literature on the estranged poor is correct, political, economic, and cultural forces outside the ghetto that disempower and impoverish it, and similar forces within the ghetto that demoralize and destroy it, are to blame for the predicament of the estranged poor. This suggests two things about blame.

First, blaming is a waste of time because everyone-politicians, capitalists, the media, the poor themselves, other Americans (living and dead) - is to blame. Second, given the complexity of the problem, spending energy on blame diverts energy sorely needed to find the necessarily multifaceted solutions - which will require the participation of all of the people being blamed. ${ }^{43}$

If blaming cannot distinguish the blameworthy from the blameless and if it can give us neither valid moral distinctions nor political purchase on how to help the estranged poor, ${ }^{44}$ how should we proceed instead? I propose to follow Robert Goodin's lead in distinguishing "causal" from "task" responsibility. The former refers to the agent or situation that created the problem; the latter refers to the moral imperative to help someone who is vulnerable to you, regardless of whether you had any role in causing the vulnerability:

People who have failed to take advantage of opportunities to avert harm to themselves may, in some sense, "have themselves to blame" for any harm that befalls them; but they rarely have only themselves to blame. Once all their opportunities for self-help have passed ... .

43. Even Wilson evades the complexity of the problem of the estranged poor by focusing his prescriptions so heavily on full employment policy. The availability of (not very attractive or lucrative) jobs will not affect some fraction of the estranged poor. Some can make too much money selling drugs, or would gain too little over their AFDC payments, to want regular employment. Others are too addicted to cocaine or alcohol, or too fearful of the racist, alien, literate world outside their neighborhood to venture far from even the worst home. This is the theme of yet another review of The Truly Disadvantaged (Jason DeParle, “. . . And Start Helping the Underclass," Washington Monthly 20 [March 1988]: 52-56) and of J. David Greenstone, "Culture, Rationality, and the Underclass" (paper presented at the Conference on The Truly Disadvantaged, Northwestern University, Evanston, Ill., October 19, 1990). Conversely, however, it is just as mistaken to assume that the jobs are there or will materialize if only we could make the poor try harder to get and keep them.

44. This is a historically contingent claim rather than a general philosophical position. In some circumstances and for some problems, blame may be normatively appropriate and politically useful. The architects of "massive resistance" to school desegregation were clearly blameworthy, and one could derive powerful arguments about how to foster social justice from that starting point. More generally, Martin Luther King was so effective partly because his moral outrage (in combination with blacks' and their allies' political pressure) was able to move many white Americans to change their behavior. But white Americans are now largely inured to claims of racial blame (see Jennifer Hochschild and Monica Herk, “'Yes, but . . .': Principles and Caveats in American Racial Attitudes," in NOMOS XXXII: Majorities and Minorities, ed. John Chapman and Alan Wertheimer [New York: New York University Press, 1990], pp. 308-35). 
the situation is beyond their control. Others, however, may still be able to act so as to avert [or correct] harm to them. To suggest that those others should (or even that they may) stand idly by and watch people reap the bitter fruits of their own improvidence is surely absurd. At that point, if not before, those who have gotten themselves into a dangerous situation truly are unable to help themselves. They are, instead, enormously (perhaps uniquely) vulnerable to the actions and choices of particular others for getting them out of the mess. On my analysis, such vulnerabilities generate strong responsibilities. ${ }^{45}$

The implication of this argument is that political actors should find those people and structures to whom the estranged poor are most vulnerable and who are best situated to alleviate that vulnerability, and then persuade or require them to act. The political process, that is, would be a search for levers for action, not an effort to pinpoint moral culpability or induce extraordinary virtue. This endeavor is hardly simple or straightforward. But it at least has the advantage of avoiding the energy-wasting moralizing so evident in reviews of The Truly Disadvantaged, and it at most would begin a chain reaction that could actually change the situation of the estranged poor.

How would the search for leverage proceed? The initial effort would entail seeing what the people to whom the estranged poor are most immediately vulnerable - their parents, mates, teachers, potential employers, police, local politicians, social workers-can do to reduce that vulnerability. If these actors are unwilling to take on task responsibility or are themselves vulnerable, one would turn one's sights outward, to the school board, the city budgeters, corporate headquarters, authors of welfare regulations, the police commissioner, and so on.

Consider a brief example. Political activists should stop worrying about whether teachers hold differentially low expectations for poor black students and should instead ask teachers what they need to be able to conduct classes safely and productively. The answer will probably include more money for books and supplies, less time spent in paperwork, and a cleaner and safer classroom. Two steps then follow. Teachers should be pressed to do everything possible to improve their students' achievement in the absence of these changes. In addition, by focusing on who is immediately responsible for implementing each change, political activists can identify the next set of links in the chain. They should then go to the principal, janitors' union, and school board-not to accuse them of indifference to the welfare of children but, rather, to ask what they would need in order to be able to provide teachers with resources, time, and cleanliness. And so on. The process is simple, and the argument is not remotely novel-I am merely suggesting that this route is likely to be more productive than one focused on blame or underlying causation. ${ }^{46}$

45. Robert Goodin, Protecting the Vulnerable: A Reanalysis of Our Social Responsibilities (Chicago: University of Chicago Press, 1985), p. 129; see more generally pp. 114-34.

46. I cannot hope to deal with the complexities of the idea of "causation" here, but let me begin by distinguishing among three meanings, only one of which is compatible 
A complete analysis and political program will eventually move far beyond the "particular others ... [able to help the estranged poor] get . . . out of the mess." It will move, that is, beyond identifiable individuals' task responsibility to "the harder question" of collective task responsibility. The question is indeed harder but Goodin's answer, with which I agree, is clear: "Those able to help, albeit not as well as those with primary responsibility, retain a residual responsibility to do so in case the others default; and they also have a continuing responsibility to monitor the situation to see whether or not their assistance is in fact required. The limit of this responsibility is, quite simply, the limit of the vulnerable agent's needs and of the responsible agent's capacity to act efficaciously-no more, but certainly no less. ${ }^{.47}$ In political terms, this precept requires that all citizens contribute to alleviating the vulnerability of the estranged poor. Their responsibility ends when the condition of estranged poverty ends, and not sooner. To continue the example above, following the chain of leverage will eventually bring the political activist to the claim that citizens must pass school bonds to raise money, mayors and state departments of education must be held accountable for corrupt school boards, employers must provide jobs for high school graduates regardless of race, suburbanites must stop buying drugs from ghetto children, men at all income levels must provide at least financial support for their children, women of all classes must relinquish activities that inhibit their children's ability to learn and mature emotionally, and so on. The chain of leverage will bring us, in short, back to all Americans' political choices, cultural preferences, economic behavior, and social activities - the point at which my analysis of the estranged poor started.

Fully developing this argument would take me far afield, into Goodin's moral consequentialism, communitarians' deontological claim that "no man is an island," social democrats' privileging of positive over negative liberty, and so on. This article is not the place for those arguments. All I can do here is to suggest a few ways to develop the model of collective task responsibility so that it has a chance of moving beyond mushy utopianism.

The basic principle is that those who can alleviate vulnerability are morally bound to do so. The more one can do, the more one must do. The political question is how to get people with collective task responsibility to act. Five rules of thumb can help to shape that tricky political process.

with task responsibility. Causation as blame- "You caused this problem by being racist, or profit-oriented, or lazy, or ..."-I have already dismissed as not helpful. Causation as deep underlying structure- "The condition of the estranged poor is caused by the legacy of slavery, or the imperatives of advanced capitalism, or the incentives of the two-party electoral system, or ..."-is important for understanding how the condition arose, but of little use in its alleviation, short of revolution. Only causation as relatively short-term, even superficial, reasons - "I can't teach these students because they are disruptive, or hungry, or have no books, or ..."-is an important component of task responsibility.

47. Goodin, pp. 134-35; see more generally pp. 134-44. 
First, do not expect people to do more than they can-that road leads simply to frustration and rejection of the whole enterprise. Second, do not easily allow people to do much less than they can-that road vitiates the basic principle and demoralizes the full contributors. Third, give people direct, even self-interested, incentives to take action-few people will participate for long in a program that asks them to sacrifice themselves or their resources to an unknown other. Fourth, give people reasons beyond direct incentives for taking action-Americans have a long history of acting to help others if they believe that their actions will be efficacious, are morally right, and are not evidence of being a sucker. ${ }^{48}$ Finally, give people reason to believe that their actions will be efficacious-if they believe the problem can be solved, they will be much more likely to try. ${ }^{49}$

Each rule of thumb warrants, and requires, detailed analysis. But instead of embarking on that long task, I turn to a final issue that both addresses a problem so far untouched-what is the task responsibility of the vulnerable themselves? - and might help reassure other Americans that they are not being suckered by the estranged poor. This is the issue that $I$ have avoided up to now - the role of racism in the politics of the estranged poor.

The Truly Disadvantaged argues that contemporary racism is a red herring. In Wilson's view, the newly thriving black middle class and the fact that the deteriorating urban job market is an economic phenomenon both show that racial discrimination does not explain the growing underclass. Racism has declined; the situation of the working class and poor has worsened for nonracial reasons; the disproportionate harm to urban blacks of the changing economy is a function of past discrimination and terrible historical luck, not of current racism (pp. 10-12).

Other analysts disagree. Again, one review of The Truly Disadvantaged must stand in for a full discussion. It criticizes Wilson for ignoring "the pure and simple fact of racism.... Class is up and race is down? Would that it were true as a guide to public policy. Class may be up, but what is down is not race but American shame toward lack of progress in reversing the disadvantage of race in America. ... The social democratic agenda [of the second half of the book] will fail to reach the truly disadvantaged because it does not address racism." 50

The huge literature on American race relations leaves no doubt in my mind that the critics are correct; racism persists and racial discrimination seriously damages black members of the estranged poor. But what matters

48. Survey research consistently shows that Americans are eager to help others in need, even at considerable cost to themselves, but are unwilling to support welfare, which has the connotation of "lazy bums getting something for nothing."

49. For example, political actors should point out how much the civil rights movement accomplished, how few of the poor are members of the dreaded "underclass," and how helpful some programs for the estranged poor have been (see Hochschild, pp. 151-53).

50. Theodore Lowi, "The Theory of the Underclass," Policy Sciences Review 7 (1988): $852-58$, emphasis in original. 
to task responsibility is less the persistence of racism than the appropriate response to it. Orlando Patterson made the point most eloquently almost two decades ago: blacks must reject all claims as victims-must even accept responsibility for their past as well as for their future - to be full moral agents: "There can be no moral equality where there is a dependency relationship among men; there will always be a dependency relationship where the victim strives for equality by vainly seeking the assistance of his victimizer. No oppressor can ever respect such a victim, whatever he may do for him, including the provision of complete economic equality. In situations like these we can expect sympathy, even magnanimity from men, but never - and it is unfair to expect otherwise - the genuine respect which one equal feels for another." ${ }^{51}$ In the hands of conservatives, this claim becomes a plea for self-help and abjuration of dependence on government hand-outs. ${ }^{52}$ In Patterson's hands, the claim implies "constructive public rebellion," in which blacks and other ethnic groups with "a potentially common class interest" create "a total, almost revolutionary change in American society." 53

Patterson's combination of tough-minded personal responsibility and expansive economic and political radicalism correctly allocates task responsibility for helping the estranged poor. The call for personal responsibility responds to the destructive values and behaviors of both the estranged poor and the mainstream affluent, as in the second and third themes developed above. It also reassures those with collective task responsibility that they are not being taken for a ride. The call for "revolutionary change in American society" addresses the political choices which created the problem of the estranged poor - the first themeand keeps pressure on those able to effect essential structural change. Most important, Patterson's refusal to allow whites to control the resolution of blacks' problems appropriately dissociates blame and long-term causation from prescription. Even if racism, intentional or institutional, helped to create and still contributes to the situation of the estranged poor, the best intentioned white outsiders cannot do all that is needed to alleviate it. Change ultimately lies in the hands of those with the most to gain and the most direct understanding of how to gain it.

51. Orlando Patterson, "The Moral Crisis of the Black American," Public Interest 23 (1973): 43-69.

52. Glenn Loury, "The Moral Quandary of the Black Community," Public Interest 79 (1985): 9-22.

53. Patterson, p. 68. 